\title{
Position Paper di AIDAP: Trattamenti psicologici basati sulle prove e non trattamenti eclettici multidisciplinari come primo approccio ai disturbi dell'alimentazione
}

\section{Position Paper di AIDAP: Evidence-based psychological treatments and not multidisciplinary eclectic treatments as first approach of eating disorders}

Riccardo Dalle Grave, Arianna Banderali, Sara Campagna, Lucia Camporese, Domenico Filardo, Francesco larrera, Marco Massa, Massimiliano Sartirana, Selvaggia Sermattei, Monica Bacchetta, Simona Calugi for AIDAP Scientific Commission

La position paper è presentata in lingua inglese e italiana/Position paper is presented in English and in Italian language

Parole chiave

Disturbi dell'alimentazione Anoressia nervosa

Bulimia nervosa

Trattamento psicologico

Trattamento multidisciplinare

Trattamento basato sull'evidenza

\section{Key words}

\section{Eating disorders}

Anorexia nervosa

Bulimia nervosa

Psychological treatment

Multidisciplinary treatment

Evidence-based treatment

\begin{abstract}
Riassunto
Le linee guida per il trattamento dei disturbi dell'alimentazione non sono ancora disponibili in Italia, tuttavia alcuni documenti di appropriatezza clinica e consenso sono stati recentemente pubblicati dal Ministero della Salute italiano e dall'Istituto Nazionale di Sanità. Questi documenti raccomandano con forte enfasi un trattamento multidisciplinare per i disturbi dell'alimentazione e scoraggiano un trattamento mono-professionale. Queste raccomandazioni, sebbene siano il risultato di un ampio consenso clinico, non tengono conto di alcuni trattamenti psicologici basati sull'evidenza per i disturbi dell'alimentazione (ad esempio, una terapia cognitivo-comportamentale migliorata (CBT-E) e la psicoterapia interpersonale (IPT)) sono forniti da un singolo terapeuta e non da team multidisciplinari. Al contrario, l'intervento eclettico multidisciplinare raccomandato non ha prove di efficacia, non essendo mai stato testato in studi randomizzati e controllati. In questa position paper, l'Associazione Italiana Disturbi dell'Alimentazione e del Peso (AIDAP) raccomanda ai servizi clinici italiani che trattano disturbi dell'alimentazione di fornire, come intervento di prima scelta, e in base all'età e alla diagnosi del disturbo, il seguente trattamento psicologico basato sull'evidenza: CBT-E (per tutte le categorie diagnostiche e l'età dei disturbi alimentari), IPT (per adulti con bulimia nervosa), trattamento basato sulla familglia (FBT) (per adolescenti con anoressia nervosa o bulimia nervosa), e Maudsley Model of Anoressia Nervosa Treatment for Adults (MANTRA) (per adulti con anoressia nervosa). La position paper raccomanda anche che i trattamenti multidisciplinari dovrebbero essere implementati e valutati solo in centri clinici altamente specializzati che offrono interventi intensivi, come il trattamento intensivo ambulatoriale, il day-hospital e il ricovero, quando i pazienti non rispondono a trattamenti psicologici ambulatoriali ben condotti.
\end{abstract}

\begin{abstract}
Guidelines for the treatment of eating disorders are not yet available in Italy, however some documents of clinical appropriateness and consensus have recently been published by the Italian Ministry of Health and the National Institute of Health. These documents recommend with strong emphasis a multidisciplinary treatment for eating disorders and discourage a mono-professional treatment. These recommendations, although they are the result of a broad clinical consensus, do not take in consideration that some evidence-based psychological treatment for eating disorders (e.g., enhanced cognitive behavior therapy (CBT-E) and interpersonal psychotherapy (IPT)) are delivered by a single therapist and not by multidisciplinary teams. On the contrary, the recommended multidisciplinary eclectic intervention has no evidence of efficacy, having never been tested in randomized controlled trials. In this position paper, the Associazione Italiana Disturbi dell'Alimentazione e del Peso (AIDAP) recommends to the Italian eating disorder clinical services to deliver, as first-line intervention, and according to the age and the eating disorder diagnosis of the patient, the following evidence-based psychological treatment: CBT-E (for all the eating disorder diagnostic categories and age), IPT (for adults with bulimia nervosa), family-based treatment (FBT) (for adolescents with anorexia nervosa or bulimia nervosa), and Maudsley Model of Anorexia Nervosa Treatment for Adults (MANTRA) (for adults with anorexia nervosa). The position paper also recommends multidisciplinary treatments should be only implemented and evaluated in some high specialized clinical centers delivering intensive treatments, such as intensive outpatient treatment, day hospital and inpatients, when the patients do not respond to well delivered outpatient evidence-based psychological treatments.
\end{abstract}

Copyright @ 2019 Riccardo Dalle Grave et al. This is an open-access article distributed under the terms of the Creative Commons Attribution License (CC BY). The use, distribution or reproduction in other forums is permitted, provided the original author(s) and the copyright owner(s) are credited and that the original publication in this journal is cited, in accordance with accepted academic practice. No use, distribution or reproduction is permitted which does not comply with these terms.

Riccardo Dalle Grave, MD (₫) rdalleg@gmail.com

Ricevuto: 28 Febbraio 2019; Accettato: 15 Marzo 2019; Pubblicato online: 27 Marzo 2019. doi:10.32044/ijedo.2019.04 


\section{Versione italiana}

La medicina non è una scienza esatta e la pratica medica e psicoterapeutica lo è ancor meno. Questo spiega perché un problema di salute grave, come i disturbi dell'alimentazione, possa essere trattato in modi anche molto diversi. All'incertezza della "scienza" medica va aggiunto infatti il diverso grado di aggiornamento del professionista che la esercita. Purtroppo, trattamenti inadeguati possono determinare effetti negativi sulla salute e sulla qualità di vita del paziente e di conseguenza aumentare i costi totali sull'economia di un Paese. Per far fronte a questi problemi, per ogni malattia, le indicazioni per le cure più idonee ed efficaci sono fornite da un insieme di strumenti (per esempio, linee guida, conferenze di consenso, valutazione di appropriatezza) che andrebbero periodicamente aggiornati. Anche se la teoria indica che gli strumenti dovrebbero rappresentare il frutto di un lavoro condiviso fra medici, pazienti, associazioni e altre professioni sanitarie, questo accade assai di rado e spesso le raccomandazioni sono fortemente influenzate dalle lobby sanitarie, farmaceutiche e politiche.

In Italia non sono ancora disponibili linee guida per il trattamento dei disturbi dell'alimentazione, ma recentemente sono stati prodotti dei documenti di appropriatezza clinica e di consenso. Il Ministero della Salute ha pubblicato due documenti. Il primo descrive l'appropriatezza clinica, strutturale e operativa nella prevenzione, diagnosi e trattamento dei disturbi dell'alimentazione (Bevere et al., 2013). Il secondo riporta le linee guida di indirizzo nazionali per la riabilitazione nutrizionale nei disturbi dell'alimentazione, (Ruocco et al., 2017). Inoltre, l'Istituto Superiore di Sanità ha pubblicato una conferenza di consenso sui disturbi del comportamento alimentare (De Virgilio et al., 2012).

L'Associazione Italiana Disturbi dell'Alimentazione e del Peso (AIDAP), che ha tra i suoi obiettivi quello di diffondere la conoscenza scientifica nell'ambito della prevenzione, educazione, trattamento e ricerca dei disturbi dell'alimentazione e problemi di peso, ha accolto con molto piacere queste iniziative che giudica meritevoli e degne di attenzione all'interno del mondo scientifico italiano. Tuttavia, AIDAP ritiene opportuno fare alcune precisazioni e aggiunte a questi documenti con l'obiettivo di fornire una corretta informazione ai professionisti della salute, ai pazienti e alle loro famiglie.

I Quaderni del Ministero della Salute raccomandano di fare studi controllati che consentano di confrontare i vari interventi psicologici individuali e familiari, a breve e a lungo termine, e di disseminare le terapie basate sull'evidenza (Bevere et al., 2013). La Conferenza di Consenso,

\section{English version}

Medicine is not an exact science, and medical and psychotherapeutic practices are even less exact. This explains why a serious health problem, such as eating disorders, can be treated in very different and often contradictory ways. The uncertainty of medical "science" must be added to the different degree of professionals' update who exercises it. Unfortunately, inadequate treatments can have negative effects on the health and quality of life of the patients and consequently increase the total country's health cost. To address these problems, for each disease, the indications for the most suitable and effective treatments are provided by a set of tools (i.e., guidelines, consensus conferences, appropriateness assessment) that should be periodically updated. Although the theory indicates that these instruments should represent the fruit of shared work among scientific societies, professional and patients, this rarely happens and often the recommendations are strongly influenced by health, pharmaceutical and political lobbies.

Guidelines for the treatment of eating disorders are not yet available in Italy, however some documents of clinical appropriateness and consensus have recently been published. The Italian Ministry of Health has published two documents. The first describes the clinical, structural and operational appropriateness in the prevention, diagnosis and treatment of eating disorders (Bevere et al., 2013). The second reports the clinical national recommendations for the nutritional rehabilitation in eating disorders (Ruocco et al., 2017). Furthermore, the Italian National Institute of Health published a consensus conference on eating disorders (De Virgilio et al., 2012).

The Associazione Italiana Disturbi dell'Alimentazione e del Peso (AIDAP), which has among its objectives to spread scientific knowledge in the field of prevention, education, treatment and research of eating disorders and weight problems, judges these initiatives important and worthy of attention within the Italian scientific world. However, AIDAP believes that there is the need to make some clarifications and additions to these documents with the aim to provide a correct information to health professionals, patients affected by eating disorders and their families.

The Italian Ministry of Health documents recommend that controlled studies be carried out to compare the various individual and family psychological interventions, both at short- and long-term, and to disseminate evidencebased therapies (Bevere et al., 2013). The Italian Consensus 
ma anche i Quaderni del Ministero della Salute, sostengono che il trattamento mono-professionale non è raccomandato e che l'approccio da garantire ai pazienti affetti da disturbi dell'alimentazione deve essere multidimensionale, interdisciplinare, multi-professionale integrato, con il coinvolgimento di medici (psichiatri/neuropsichiatri infantili, nutrizionisti clinici, internisti/pediatri), psicologi, psicoterapeuti, dietisti, infermieri, educatori professionali.

A nostro avviso in queste raccomandazioni ci sono delle importanti contraddizioni che meritano di essere spiegate. I trattamenti psicologici, come la Terapia Cognitivo Comportamentale Migliorata (CBT-E), il trattamento basato sulla famiglia (FBT), il Maudsley Model of Anorexia Nervosa Treatment for Adults (MANTRA) e la Psicoterapia Interpersonale (IPT), sono le sole terapie basate sull'evidenza scientifica, disponibili per i disturbi dell'alimentazione e raccomandate dalle linee guida internazionali (Hay et al., 2014; National Institute for Health and Care and Clinical Excellence, 2017). È da sottolineare che alcuni trattamenti psicologici hanno che hanno dimostrato un'efficacia nei disturbi dell'alimentazione (per. es. CBT-E e IPT) sono stati somministrati da un singolo terapeuta e non da un'équipe multidisciplinare. Al contrario, l'intervento multidisciplinare eclettico raccomandato dai Quaderni della Salute e dalla Conferenza di Consenso non ha evidenze di efficacia, non essendo mai stato testato in rigorosi studi randomizzati e controllati. Tale intervento, sebbene sia inevitabile in pazienti fortemente malnutriti e complessi e in contesti di cura intensivi (terapia ambulatoriale intensiva, il day-hospital e il ricovero), presenta vantaggi e svantaggi.

Il vantaggio principale è che la presenza di clinici con competenze multiple ed eterogenee può facilitare la gestione di pazienti con gravi problemi medici e psichiatrici coesistenti al disturbo dell'alimentazione, un sottogruppo di pazienti tipicamente trattato nei luoghi intensivi di cura come il day-hospital o il ricovero. Gli svantaggi possono essere divisi in quattro categorie principali. Primo, un trattamento con molteplici terapeuti incoraggia i pazienti a parlare di problemi specifici con specifici terapeuti. Il risultato è che nessun terapeuta osserva e apprezza l'intero quadro clinico del paziente. Secondo, l'applicazione di un trattamento da parte di terapeuti che condividono la loro conoscenza, senza un modello teorico e clinico condiviso, facilita la comunicazione di informazioni contradditorie ai pazienti sul loro disturbo e sulle strategie per affrontarlo. Questo può creare confusione nei pazienti sui problemi da affrontare per superare il disturbo dell'alimentazione e far sviluppare la sensazione di non essere in controllo durante il trattamento. Inoltre, rischia di aumentare le divisioni e
Conference, but also the Italian Ministry of Health documents, claims that mono-professional treatment is not recommended and that the approach for patients with eating disorders should be multidimensional, interdisciplinary, multi-professional integrated, with the involvement of medical doctors (psychiatrists/child psychiatrists, internists/pediatricians), psychologists, psychotherapists, dietitians, nurses, and professional educators). In our opinion, in these recommendations there are some contradictions that deserve to be explained.

Psychological treatments, such as Enhanced Cognitive Behavioral Therapy (CBT-E), Family-Based Treatment (FBT), Maudsley Model of Anorexia Nervosa Treatment for Adults (MANTRA) and Interpersonal Psychotherapy (IPT), are the only evidence-based therapies available for eating disorders and recommended by international guidelines (Hay et al., 2014; National Institute for Health and Care and Clinical Excellence, 2017). It should be emphasized that some evidence-based psychological treatments for eating disorders (e.g., CBT-E and IPT) are delivered by a single therapist and not by multidisciplinary teams. On the contrary, the multidisciplinary eclectic intervention recommended by the Italian Ministry of Health and the Consensus Conference documents has no evidence of efficacy, having never been tested in rigorous randomized controlled trials. This intervention, although unavoidable in severely underweight and complex patients and in intensive settings of care (i.e, intensive outpatient therapy, day hospital and inpatient), presents advantages and disadvantages.

The main advantage is that the presence of clinicians with multiple and heterogeneous skills can facilitate the management of patients with serious medical and psychiatric problems coexisting with the eating disorder, a subgroup of patients typically treated in intensive settings of care places such as day hospital or inpatient. The disadvantages can be divided into four main categories. First, treatment with multiple therapists encourages patients to talk about specific problems with specific therapists. The result is that no therapist observes and appreciates the entire clinical picture of the patient. Second, the application of treatment by therapists who share their knowledge, without a shared theoretical and clinical model, facilitates the communication of contradictory information to the patients about their disorder and the strategies and procedures to address it. This can create confusion in patients about problems to be addressed in order to overcome the eating disorder and to develop of the feeling of not being in control during the treatment. Moreover, it increased the risks to develop divisions and conflicts between team members 
conflittualità tra i membri dell'équipe che possono avere convinzioni diverse sulle modalità di cura e sui problemi che devono essere affrontati. La divisione e le conflittualità dell'équipe possono essere utilizzate dai pazienti per aumentare la loro resistenza alla cura. Terzo, i trattamenti multidisciplinari sono molto costosi, un fatto da tenere sempre in grande considerazione in un momento di crisi economica e finanziaria. Infine, i trattamenti multidisciplinari eclettici sono difficili da replicare e disseminare.

Con i trattamenti psicologici basati sull'evidenza, somministrati da un singolo terapeuta in $20-40$ sedute, i due terzi dei pazienti che concludono il trattamento (circa l'80\%) raggiunge una remissione completa e duratura dal disturbo dell'alimentazione. Per questo motivo, AIDAP raccomanda ai servizi clinici italiani di disturbi alimentari di fornire, come prima scelta d'intervento ed in base all'età e alla diagnosi del disturbo alimentare del paziente, il seguente trattamento psicologico basato sull'evidenza:

- CBT-E per tutte le categorie diagnostiche e l'età dei disturbi alimentari

- IPT per adulti con bulimia nervosa

- MANTRA per adulti con anoressia nervosa

- FBT per adolescenti con anoressia nervosa o bulimia nervosa

I vantaggi di questi interventi, oltre alla loro efficacia, sono i bassi costi e il non fornire informazioni contraddittorie ai pazienti. In questo modo si può ottenere un miglioramento degli standard di cura senza aumentare le risorse finanziare dedicare ai servizi clinici che trattano i disturbi dell'alimentazione. Purtroppo, come sottolineato dai Quaderni del Ministero della Salute, "nonostante gli importanti progressi ottenuti con lo sviluppo di psicoterapie basate sull'evidenza, questi trattamenti sono raramente applicati al di fuori dei luoghi di ricerca e, ancora oggi, molti pazienti in Italia continuano a ricevere interventi subottimali".

I trattamenti multidisciplinari dovrebbero essere implementati solo in centri clinici altamente specializzati che hanno la disponibilità di interventi intensivi di cura, come il trattamento ambulatoriale intensivo, il day hospital e il ricovero, a cui i clinici possono inviare i pazienti che non rispondono ai trattamenti psicologici basati sull'evidenza. Anche in questi centri di riferimento, comunque, è raccomandato, al fine di fornire un approccio coerente e non contradditorio, che i terapeuti, pur mantenendo i loro ruoli professionali specifici, condividano la stessa filosofia e teoria, utilizzino trattamenti psicologici basati sull'evidenza e un linguaggio comune con i pazienti, ed eseguano who may have different beliefs about the strategies to use and the problems to address to treat the patients with eating disorders. The division and conflicts of the team can be used by patients to increase their resistance to treatment. Third, multidisciplinary treatments are very expensive, a fact that should always be taken into great consideration at a time of economic and financial crisis. Finally, eclectic multidisciplinary treatments are difficult to replicate and disseminate.

With the evidence-based psychological treatments delivered by a single therapist in 20-40 sessions, two thirds of the patients who complete the treatment (about 80\%) achieve a complete and lasting remission from their eating disorder. For this reason, AIDAP recommends to the Italian eating disorder clinical services to deliver, as firstline intervention and according to the age and the eating disorder diagnosis of the patient, the following evidencebased psychological treatment:

- CBT-E for all the eating disorder diagnostic categories and age

- IPT for adults with bulimia nervosa

- MANTRA for adults with anorexia nervosa

- FBT for adolescents with anorexia nervosa or bulimia nervosa

The advantages of evidence-based psychological interventions, in addition to their effectiveness, are the low costs and the coherent and not contradictory information delivered to the patients. In this way it is possible to obtain an improvement of the standards of care without increasing the financial resources dedicated to the clinical services that treat eating disorders. Unfortunately, as underlined by the Italian Ministry of Health documents, "despite the important progress made with the development of evidence-based psychotherapies, these treatments are rarely applied outside research sites and, most patients continue to receive suboptimal interventions in Italy".

Multidisciplinary treatments should only be implemented in some high specialized clinical centers delivering intensive treatments, such as intensive outpatient treatment, day hospital and inpatients, when the patients do not respond to well delivered outpatient evidence-based psychological treatments. Even in these centers, however, it is recommended, in order to provide a coherent and non-contradictory approach, that therapists, while maintaining their specific professional roles, share the same philosophy and theory, use evidence-based psychological strategies and a common language with patients, and perform periodic meetings 
incontri periodici tra di loro e con il paziente per discutere i vari elementi del trattamento e la relazione tra loro.

Infine, AIDAP raccomanda che tutti i centri clinici che adottano un approccio multidisciplinare, valutino gli esiti dei loro interventi attraverso studi longitudinali osservazionali, con outcome valutati possibilmente da operatori neutri, per capire se e quando è conveniente investire risorse economiche in questi interventi complessi e costosi.

\section{Messaggi chiave}

1. Numerose ricerche, alcune eseguite anche in Italia, hanno dimostrato l'efficacia di trattamenti psicologici, come la CBT-E e la IPT, somministrati da un singolo terapeuta nella gestione dei disturbi dell'alimentazione

2. Con queste terapie basate sull'evidenza, i due terzi dei pazienti con disturbi dell'alimentazione che conclude il trattamento raggiunge una remissione duratura in 20-40 sedute.

3. L'approccio multidisciplinare è potenzialmente più utile per i pazienti gravemente malnutriti e complessi e in contesti di cura più intensivi, come per esempio la terapia ambulatoriale intensiva, il day-hospital o il ricovero riabilitativo.

4. L'approccio multidisciplinare andrebbe preferibilmente somministrato da équipe che adottano un orientamento teorico comune e che faccia riferimento ai trattamenti psicologici basati sull'evidenza.

5. L'esito del trattamento condotto nei servizi clinici che usano approcci multidisciplinari e eclettici dovrebbe essere valutato. between clinicians and the patient to discuss the various elements of the treatment and the relationship between them.

Finally, AIDAP recommends that all the clinical centers adopting a multidisciplinary approach assess the outcome of their intervention with longitudinal assessment studies made by neutral operators, to understand if and when it is convenient to invest economic resources in these expensive and complex treatments.

\section{Key messages}

1. Several studies, some done also in Italy, have showed the efficacy of outpatient psychological treatments, such as CBT-E and IPT, administered by a single therapist in the management of eating disorders.

2. With evidence-based psychological treatments, two thirds of patients with eating disorders that conclude the treatment reach a lasting remission in 20-40 sessions.

3. The multidisciplinary approach is potentially more useful for severely underweight and complex patients and in intensive care settings, such as intensive outpatient therapy, day hospital or inpatient.

4. The multidisciplinary approach should preferably be delivered by teams that adopt a common theoretical orientation based on psychological evidence-based treatments.

5. The outcome of the treatment delivered in clinical services using a multidisciplinary and eclectic approach should be assessed.

\section{Bibliografia/References}

Bevere, F., Borrello, S., Brambilla, F., Dalle Grave, R., De Lorenzo, A., Di Fiandra, T., ... Siracusano, A. (2013). Appropriatezza clinica, strutturale e operativa nella prevenzione, diagnosi e terapia dei disturbi dell'alimentazione. Quaderni del Ministero della Salute(17/22).

De Virgilio, G., Coclite, D., Napoletano, A., Barbina, D., Dalla Ragione, L., Spera, G., \& Di Fiandra, T. (2012). Conferenza di consenso. Disturbi del Comportamento Alimentare (DCA) negli adolescenti e nei giovani adulti. Roma: Istituto Superiore di Sanità.

Hay, P., Chinn, D., Forbes, D., Madden, S., Newton, R., Sugenor, L., ... Ward, W. (2014). Royal Australian and New Zealand College of Psychiatrists clinical practice guidelines for the treatment of eating disorders. Australian and New Zealand Journal of Psychiatry, 48(11), 977-1008. doi:10.1177/0004867414555814

National Institute for Health and Care and Clinical Excellence. (2017). Eating disorders: recognition and treatment | Guidance and guidelines | NICE. Retrieved from https://www.nice.org.uk/guidance/ng69

Ruocco, G., Andrioli Stagno, R., Ballardini, D., Cotugno, A., Dalla Ragione, L., Dalle Grave, R., ... Vincenzi, M. (2017). Linee di indirizzo nazionali per la riabilitazione nutrizionale nei disturbi dell'alimentazione. Quaderni del Ministero della Salute(29). 